\title{
Effect of Scarification, Seed Storage Temperature, and Relative Humidity on Lupinus havardii Wats. and Lupinus texensis Hook. Seed Germination
}

\author{
Wayne A. Mackay \\ Texas A\&M University-Dallas, Texas Agricultural Experiment Station, 17360 \\ Coit Road, Dallas, TX 75252-6599
}

Additional index words. sexual propagation, lupine

\begin{abstract}
Seeds of Lupinus havardii Wats. and L. texensis Hook. were subjected to scarification, storage temperature $\left(4\right.$ or $\left.22{ }^{\circ} \mathrm{C}\right)$, and relative humidity $(\mathrm{RH})$ treatments $(11 \%$, $23 \%, 52 \%, 75 \%$, or $97 \% \mathrm{RH}$ ) for 12 months. Seed moisture increased as relative humidity increased with scarified seed having the greatest increase in seed moisture content regardless of storage temperature. For both species, the combination of seed scarification before storage, $75 \% \mathrm{RH}$, and $22^{\circ} \mathrm{C}$ storage temperature resulted in a significant and rapid decline in germinability beginning at 4 months. Scarified $L$. texensis seed stored at $52 \%$ RH and $22{ }^{\circ} \mathrm{C}$ also exhibited a significant decline in germinability following 6 months storage. Seed of both species stored under all other conditions germinated similar to or higher than the initial germination rate after 12 months. These results clearly show that scarification can be performed before seed packaging as long as the seed packets are stored at $\leq \mathbf{2 3} \% \mathrm{RH}$ under 4 or $22{ }^{\circ} \mathrm{C}$ with no loss in germinability for at least 1 year.
\end{abstract}

Lupinus havardii Wats. and Lupinus texensis Hook. are showy winter annuals commonly known as bluebonnets. Lupinus havardii-Big Bend or Chisos bluebonnet-grows in a narrow geographic range along the Texas-Mexico border (Andrews, 1986). The plant has 0.5- to 1-m-tall blue, fragrant flower spikes that have considerable potential as a cut flower crop (Davis et al., 1994; Mackay and Davis, 1998). Occurrence of native populations is highly variable depending upon the distribution of annual rainfall. Fall rains are the apparent trigger of germination and emergence of seedlings. In moist years, plants are distributed from the desert floor to the mountain slopes while in dry years the population is restricted to the edges of roads and areas where water collects following brief rains. In some areas, populations may not be present for 10 years or more until conditions are conducive to seed germination and plant growth.

The most popular and widespread bluebonnet, $L$. texensis, is a winter annual that produces predominately violet-blue racemes in early to midspring in central Texas. This species is widely used to provide impressive floral displays along roadsides throughout much of the state (Andrews, 1986). Recently, L. texensis has been produced and marketed as bedding plants for use in the landscape (Davis et al., 1994). Cultivars developed to broaden the appeal of this plant include 'Abbott Pink' the first seed-propagated cultivar to be developed from this program (Parsons and Davis, 1993), 'Barbara Bush' with novel lavender shade flowers (Parsons et al., 1994) and 'Texas Maroon' with novel maroon color flowers (Mackay et al., 2000).

Received for publication 26 May 2004. Accepted for publication 3 Dec. 2004.
Like many legumes, $L$. texensis and $L$. havardii seeds have hard coats that are impervious to water. This presumably is an adaptive mechanism for species survival during the long periods between moist years. However, the hard seedcoat results in erratic germination and poor seedling stands in landscapes and commercial production. Studies with these and related lupine species indicate that sulfuric acid scarification promotes uniform and rapid germination(Davis et al., 1991; Horn and Hill, 1974; Mackay et al., 1995, 1996, 2001; Shedron and Weiler, 1982). However, antidotal information indicated that seed viability declines during storage of scarified seed resulting in the recommendation to not scarify seed before storage (Andrews, 1986). As such, nonscarified seed is marketed in seed packets with resultant poor germination for the consumer. The objective of the current investigation was to determine the effects of acid scarification, relative humidity, and temperature on seed viability following seed storage. This information will be useful for seed storage and distribution methods for the seed producers of L. texensis and L. havardii.

\section{Materials and Methods}

Fresh $L$. texensis seed were mechanically harvested in Fredericksburg, Texas, and L. havardii seed were hand-harvested by the author near Presidio, Texas. The fresh seed $(8,000$ of each species) were scarified in concentrated $(36 \mathrm{~N})$ sulfuric acid for $40 \mathrm{~min}$ (L. texensis) or $120 \mathrm{~min}$ (L. havardii) at $22^{\circ} \mathrm{C}$. The time of scarification was based upon preliminary scarification experiments using four 50 seed samples of the freshly-collected seed and previous research (Davis et. al., 1991; Mackay et al., 1995). Following scarification, seed were rinsed with distilled water three times and air dried. Seed were divided into 40 groups of 200 seeds for each species and placed into individual paper seed packets. Eight thousand non-scarified seeds each of L. texensis and L. havardii were also placed into individual paper seed packets as described above.

Seed storage procedures. The seed packets described above were placed on wire screens supported $1 \mathrm{~cm}$ above a chemical desiccant in sealed plastic containers. Humidity was controlled by using saturated potassium sulfate, sodium chloride, magnesium nitrate, potassium acetate, and lithium chloride to achieve $97 \%$, $75 \%, 52 \%, 23 \%$ and $11 \% \mathrm{RH}$, respectively (Copeland, 1976). For each relative humidity treatment there were eight containers for a total of 40 containers. Each container held four seed packets, one each of scarified or non-scarified seed of L. texensis or L. havardii. Four containers for each relative humidity treatment were placed in the dark either under $4^{\circ} \mathrm{C}$ or $22^{\circ} \mathrm{C}$. Samples were removed at 0 (control) and monthly for 12 months.

Seed germination. Non-scarified seed were scarified using the protocol outlined above prior to germination tests. For germination tests, ten seeds sampled from each packet were placed on top of two sheets of moistened filter paper placed in individual $25 \times 100 \mathrm{~mm}$ glass petri dishes, a total of 160 petri dishes for each germination test. Petri dishes were placed in a seed germination chamber adding water as necessary to maintain constant moisture. Seed were germinated under a 12 -h photoperiod provided by cool-white fluorescent lamps and a $12 \mathrm{~h}$ day/night temperature regime of $25 / 20$ ${ }^{\circ} \mathrm{C}$ (Davis et al., 1991; Mackay et al., 1995). Germination, defined by radicle emergence $\geq 2$ $\mathrm{mm}$, was recorded at 24-h intervals for $10 \mathrm{~d}$. If a seed did not imbibe moisture within $24 \mathrm{~h}$, the seed was hand scarified with a razor blade to allow imbibition and germination.

Seed moisture content. To determine initial seed moisture content, four 100 -seed replicates of L. havardii and L. texensis seeds were weighed, placed in $25 \times 100 \mathrm{~mm}$ open Pyrex petri dishes and dehydrated for 48 hours at 105 ${ }^{\circ} \mathrm{C}$ in a drying oven. Dehydrated seed were reweighed after they had cooled to determine initial seed moisture content. Seeds were placed back in the drying oven for an additional $24 \mathrm{~h}$ and weighed again to verify that seeds had reached final dry weight. At the end of the experiment (12 months) four 50 seed replicates from each treatment combination were weighed, placed in $25 \times 100 \mathrm{~mm}$ open Pyrex petri dishes, dehydrated at $105^{\circ} \mathrm{C}$ in a drying oven and weighed daily for $7 \mathrm{~d}$ to determine seed moisture content.

The experimental design was a split-split plot with temperature treatments the main plots and relative humidity and scarification treatments the subplots. The two species were analyzed separately. Statistical analyses were conducted using the PC SAS General Linear Models package (SAS ver. 3.1). A square root transformation was performed on percent germination data prior to analysis to achieve a more normalized distribution. However, data presented in the figures is percentile data for 
clarity of presentation. Polynomial regression equations were calculated and presented where significant. Both scarified and non-scarified seed stored under $97 \% \mathrm{RH}$ in both $4^{\circ} \mathrm{C}$ and $22^{\circ} \mathrm{C}$ rotted within two months and the data was not included in the analysis.

\section{Results and Discussion}

Seed moisture: L. texensis. Seed stored at 22 ${ }^{\circ} \mathrm{C}$ and high relative humidity increased more in seed moisture content than the seed at the $4{ }^{\circ} \mathrm{C}$.
The initial seed moisture content was $6.89 \% \pm$ $0.04 \%$. Following 12 months of storage scarified seed stored at either 4 or $22^{\circ} \mathrm{C}$ exhibited a quadratic increase in seed moisture content as RH increased while nonscarified seeds stored at 4 or $22{ }^{\circ} \mathrm{C}$ exhibited a sigmoidal response for seed moisture content (Fig. 1A). All seed stored under $11 \% \mathrm{RH}$ contained less seed moisture compared to the initial seed moisture content. Scarified and nonscarified seed stored at 23\% $\mathrm{RH}$ and $22{ }^{\circ} \mathrm{C}$ had slightly less seed moisture content compared to the initial seed moisture
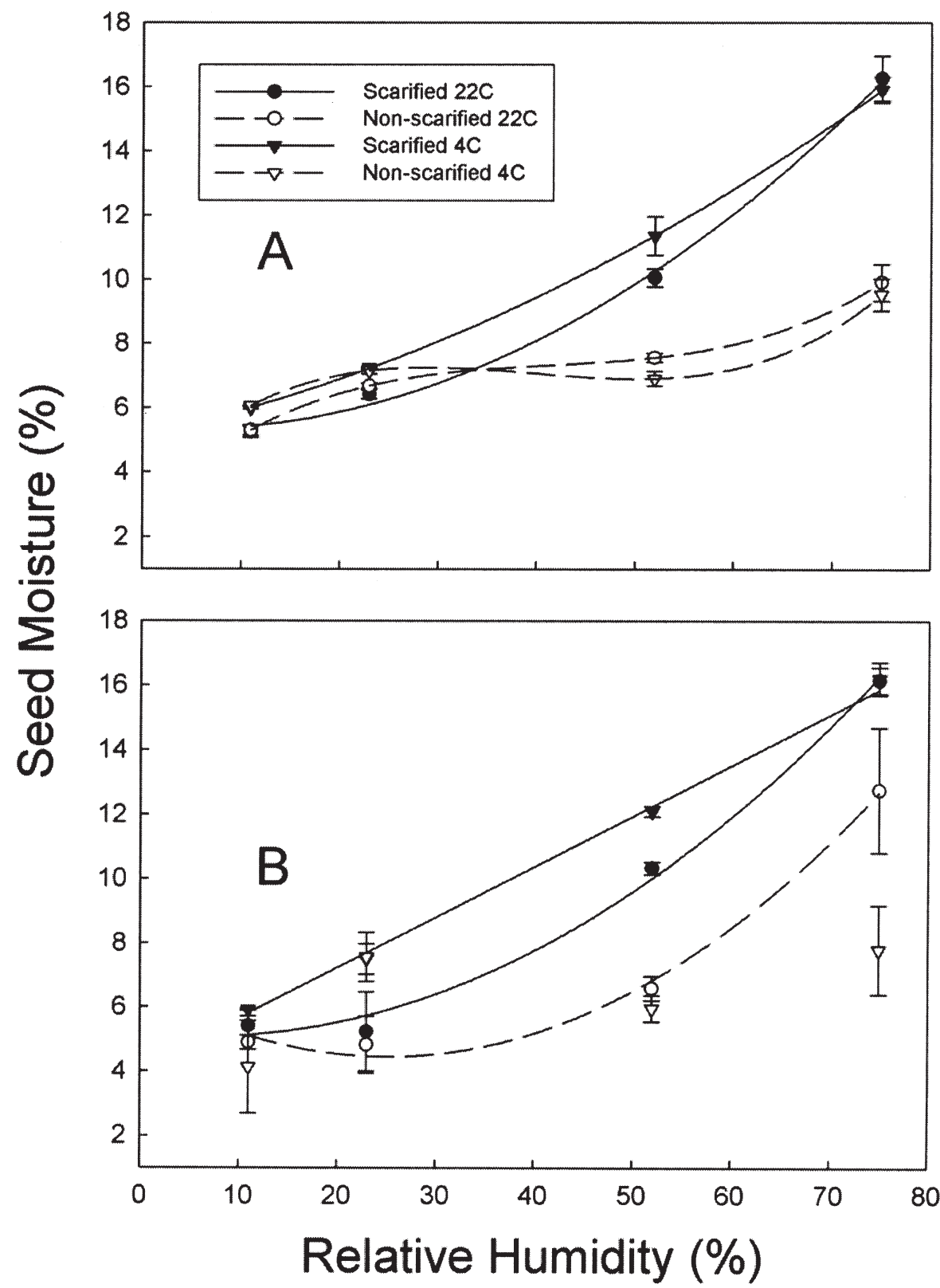

Fig. 1. Lupinus texensis (A) and L. havardii (B) seed moisture content, following 12 months storage, of seed either scarified or nonscarified stored at 4 or $22{ }^{\circ} \mathrm{C}$. Seed moisture content before storage treatments were $6.89 \% \pm 0.04 \%$ and $6.08 \% \pm 0.32 \%$ for L. texensis (A) and L. havardii (B), respectively. The regression equations and $R^{2}$ values for $L$. texensis $(\mathbf{A})$ where significant $(P \leq 0.05)$ are scarified $22{ }^{\circ} \mathrm{C} y=5.3741-0.0189 \mathrm{x}+0.0022 \mathrm{x}^{2}, R^{2}=0.97$; nonscarified $22{ }^{\circ} \mathrm{C} \mathrm{y}=2.8138+0.2928 \mathrm{x}-0.0067 \mathrm{x}^{2}$ $+0.0001 \mathrm{x}^{3}, R^{2}=0.91$; scarified $4{ }^{\circ} \mathrm{C} \mathrm{y}=5.1417+0.0669 \mathrm{x}^{2}+0.0010 \mathrm{x}, R^{2}=0.97$; nonscarified $4{ }^{\circ} \mathrm{C} \mathrm{y}$ $=3.4634+0.3242 \mathrm{x}-0.0088 \mathrm{x}^{2}+0.0001 \mathrm{x}^{3}, R^{2}=0.87$. The regression equations and $R^{2}$ values for $L$. havardii $(\mathbf{B})$ where significant are scarified $22^{\circ} \mathrm{C} y=5.1783-0.0307 \mathrm{x}+0.0024 \mathrm{x}^{2}, R^{2}=0.93$; nonscarified $22{ }^{\circ} \mathrm{C}$ y $=6.5393-0.1666 \mathrm{x}+0.0033 \mathrm{x}^{2}, R^{2}=0.75$; scarified $4{ }^{\circ} \mathrm{C} \mathrm{y}=3.9454+0.1614 \mathrm{x}, R^{2}=0.98$. Vertical bars represent standard errors of the means $(n=4$, sample $=50)$.

content while seed stored at $4{ }^{\circ} \mathrm{C}$ had slightly higher seed moisture content. Scarified seed stored under $52 \%$ and $75 \%$ RH had significantly higher moisture content than the nonscarified seed at $52 \%$ or at $75 \% \mathrm{RH}$.

Seed moisture: L. havardii. The responses of L. havardii seeds to the treatment combinations were slightly different from that of $L$. texensis. Following 12 months of storage scarified seed stored at $4{ }^{\circ} \mathrm{C}$ exhibited a linear increase in seed moisture content, while seed stored at $22{ }^{\circ} \mathrm{C}$ exhibited a quadratic increase in seed moisture content as RH increased. Nonscarified seed stored at $22{ }^{\circ} \mathrm{C}$ exhibited a quadratic response for seed moisture content, while nonscarified seed stored at $4{ }^{\circ} \mathrm{C}$ had no significant response to increasing RH treatments. Initial seed moisture content was $6.08 \% \pm 0.32 \%$ and following 12 months of storage, moisture content of the scarified and nonscarified seed stored under $11 \% \mathrm{RH}$ was statistically the same or lower than the initial seed moisture (Fig. 1B). Scarified and nonscarified seed stored at $23 \% \mathrm{RH}$ and $22{ }^{\circ} \mathrm{C}$ had seed moisture content similar to the initial seed moisture while seed stored at $4{ }^{\circ} \mathrm{C}$ had significantly higher seed moisture content. Scarified seeds had significantly more moisture content at $52 \%$ or $75 \%$ RH than the nonscarified seed at $52 \%$ or $75 \% \mathrm{RH}$.

Seed germination: L. texensis. Time to germination did not change throughout the experiment for either species with $>90 \%$ of the seeds that germinated in both species imbibing water and germinating within $48 \mathrm{~h}$. In general, both scarified and nonscarified seed stored at $4{ }^{\circ} \mathrm{C}$ under $11 \%, 23 \%, 52 \%$, and $75 \% \mathrm{RH}$ exhibited a quadratic germination response with an increase in germinability following 6 to 8 months of storage then a gradual decline in germinability (Fig. 2A and B). However, this response was significant only for scarified seed stored under $23 \%$ and $52 \%$ RH and nonscarified seed stored under $11 \%$ and $23 \% \mathrm{RH}$.

In contrast to seeds stored at $4^{\circ} \mathrm{C}$, scarified and nonscarified seeds stored at $22^{\circ} \mathrm{C}$ exhibited a different pattern of germinability over time. Scarified seed stored at $22^{\circ} \mathrm{C}$ did not exhibit an increase in germinability compared to the initial germination rates and had a significant decline in germination rates when stored under $52 \%$ and $75 \%$ RH (Fig. 2C). Scarified seed stored under these treatments exhibited a quadratic germination response with the scarified seed stored under $75 \% \mathrm{RH}$ having a rapid decline in germinability at 4 months storage with $<20 \%$ of the seeds germinating at 6 months and no seeds germinating at 12 months. Germinability of scarified seeds stored under $52 \% \mathrm{RH}$ was initially similar to the initial seed germination rate and then exhibited a decline following 10 months storage. Nonscarified seed stored at $22{ }^{\circ} \mathrm{C}$ and $11 \%, 23 \%$, or $52 \% \mathrm{RH}$ exhibited a linear or quadratic increase in germination response during storage with seeds in the $11 \%$ and $23 \%$ RH treatments exhibiting a near $100 \%$ germinability following 12 months storage, while the nonscarified seed stored under $75 \%$ RH exhibited no significant difference in germination response compared to the control of 0 month (Fig. 2D).

Seed germination. L. havardii. RH treat- 

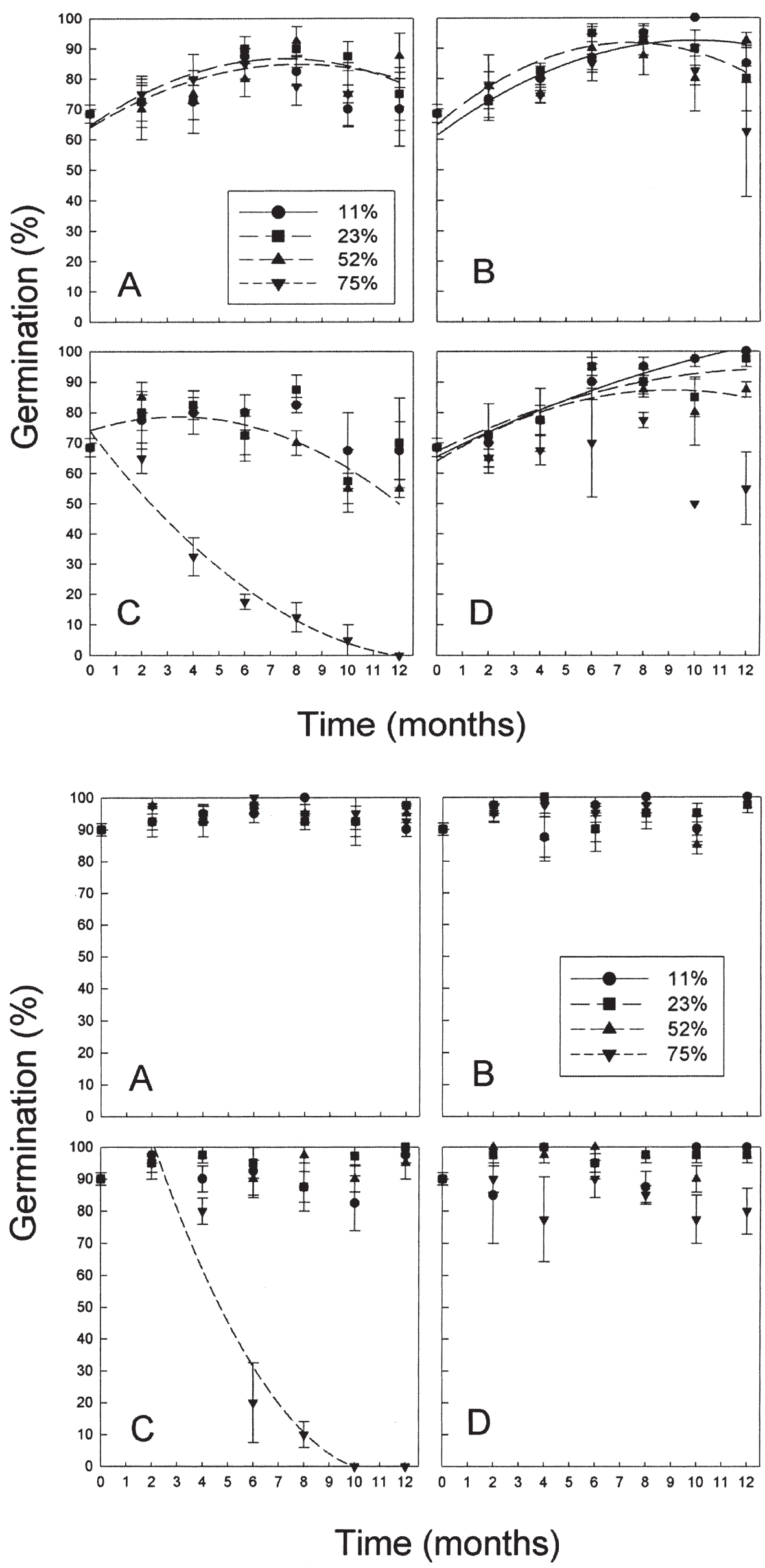

Fig. 2. Effects of storage temperature, relative humidity, scarification and time in storage on germination of $L$. texensis seed. Seed stored at 4 ${ }^{\circ} \mathrm{C}$ either scarified(A) or nonscarified (B) and seed stored at $22^{\circ} \mathrm{C}$ either scarified $(\mathbf{C})$ or nonscarified (D) under relative humidity treatments of $11 \%$, $23 \%, 52 \%$, or $75 \%$. The regression equations and $R^{2}$ values where significant $(P<0.05)$ are $(\mathbf{A})$ $23 \%$ RH y $=64.74+6.1200 \mathrm{x}-0.4150 \mathrm{x}^{2}, R^{2}=$ $0.33 ; 52 \%$ RH y $=67.37+2.4018 \mathrm{x}-0.0521 \mathrm{x}^{2}$, $R^{2}=0.29$; (B) $11 \%$ RH y $=64.75+5.1872 \mathrm{x}$ $-0.2464 \mathrm{x}^{2}, R^{2}=0.46 ; 23 \%$ RH y $=64.81+$ $7.2232 \mathrm{x}-0.4836 \mathrm{x}^{2}, R^{2}=0.41$; (C) $52 \% \mathrm{RH} \mathrm{y}=$ $74.16+2.6250 \mathrm{x}-0.3869 \mathrm{x}^{2}, R^{2}=0.50 ; 75 \% \mathrm{RH}$ $\mathrm{y}=73.92-11.0804 \mathrm{x}+0.4092 \mathrm{x}^{2}, R^{2}=0.89 ;$ (D) $11 \%$ RHy $=65.53+4.232 \mathrm{x}-0.1042 \mathrm{x}^{2}, R^{2}=0.63$; $23 \%$ RH y $=67.25+4.0982 \mathrm{x}-0.1563 \mathrm{x}^{2}, R^{2}=$ $0.42 ;$ (C) $52 \%$ RH y $=64.10+5.125 x-0.2327 x^{2}$, $R^{2}=0.33$. Germination was scored daily for 10 d. Vertical bars represent standard errors of the means $(n=4$, sample $=10)$.

ments did not affect seed germination for either scarified or nonscarified seeds stored at $4{ }^{\circ} \mathrm{C}$ (Fig. 3A and B) with germination following 12 months of storage near $100 \%$ RH. Similarly, scarified and nonscarified seeds stored at 22

${ }^{\circ} \mathrm{C}$ under $11 \%, 23 \%$, or $52 \%$ RH also exhibited high germination rates even after 12 months of storage (Fig. 3C and D). However, scarified seeds stored at $75 \% \mathrm{RH}$ had a quadratic germination response with a rapid loss in germinability exhibiting $<23 \%$ germination at 6 months, $<3 \%$ germination at 10 months and no germination at 12 months (Fig. 3C ).

Effect of storage on scarification treatment. Following 4 months in storage, scarification treatments that were used for L. texensis and L. havardii seed imbibition and germination at the beginning of the experiment were not effective in scarifying all of the nonscarified seeds as indicated by the lack of seed imbibition at $24 \mathrm{~h}$ (data not shown). However, scarification of the nonimbibed seed by hand resulted in imbibition followed by germination in most seed. Following 6 months of storage, about $40 \%$ of the L. texensis seeds did not imbibe water when placed in the germination chamber and hand scarification was necessary to achieve imbibition and resultant germination. The number of seeds that did not imbibe following scarification at 8,10 , or 12 months storage was not significantly different from 6 months. The pattern was similar for $L$. havardii, although the number of seeds that required hand scarification was about $10 \%$. For both species, $\mathrm{RH}$ treatment did not significantly affect the change in seedcoat hardness. Seeds scarified before storage did not require hand scarification following the storage treatment for imbibition and germination in either species.

Seed moisture content of $L$. texensis and $L$. havardii scarified seeds was similar to the hygroscopic equilibrium relationships described

Fig. 3. Effect of storage temperature, relative humidity, scarification and time in storage on germination of $L$. havardii seed. The regression equation and $R^{2}$ value where significant $(P \leq 0.01)$ are $(\mathbf{C})$ $75 \%$ RH y $=149.25-26.0312 \mathrm{x}+1.1272321 \mathrm{x}^{2}$, $R^{2}=0.90$. Germination was scored daily for 10 $d$. Vertical bars represent standard errors of the means $(\mathrm{n}=4$, sample $=10)$ 
for wheat (Triticum aestivum L.) and rice (Oryza sativa L.) (Roberts, 1972) stored under similar RH and temperature conditions. Seed moisture content was much lower for nonscarified seed of both species when compared to scarified seed stored under the higher relative humidity treatments, indicating that the hard seedcoat limited moisture uptake during storage. And although seed moisture content was affected by relative humidity during storage, seed moisture content alone was not associated with a decrease in seed germination. This is supported by the fact that only the combination of scarification, $\mathrm{RH} 52 \%$ or $75 \%$ and $22^{\circ} \mathrm{C}$ storage temperature resulted in a decrease in seed germination. Previous research with Phlox drummondii W.J. Hooker, indicated that seed moisture content of 5\% delayed seed germination (Carpenter et al., 1993), but our work with $L$. havardii and $L$. texensis did not show a delay in germination in seed with low seed moisture content, regardless of the scarification or storage temperature treatment.

Lupinus texensis and L. havardii exhibited different germination responses following storage under the various treatments. This may be the result in a difference in harvesting method. Lupinus havardii was harvested by hand with only the fully ripe seed pods removed and processed for this experiment, whereas L. texensis seed collection was done as a once-over harvest by machine resulting in a range of seed maturation at harvest. Seeds tested in the experiment potentially could have been at different stages of final maturation. Previous L. texensis seed germination experiments using seeds from four commercial seed lots resulted in germination rates that were $85 \%$ or greater for acid-scarified seeds (Davis et al., 1991) which is similar to the nonscarified seed stored 6 months or more in this study. However, the authors noted differences in germination between the lots in that study, but no information is available for the age of the seed in the different lots (Davis, personnel communication). In this study, our results indicate that there may be a delay in germinability following commercial machine harvest of $L$. texensis. However, further testing is necessary to determine if this is a common occurrence in commercially harvested $L$. texensis seeds.

Although Andrews (1986) discourages scarification of seeds before storage, our results clearly show that scarification can be performed before seed packaging as long as the seed packets are stored at $\leq 23 \%$ RH under 4 or $22{ }^{\circ} \mathrm{C}$ with no loss in germinability for at least one year following seed harvest and treatment. These results also confirm the author's previous experience that scarified seed stored under cool dry conditions were able to germinate and grow as well as freshly scarified seed.

\section{Literature Cited}

Andrews, J. 1986. The texas bluebonnet. Univ. Texas Press, Austin.

Carpenter, W.J., E.R. Ostmark, and J.A. Cornell. 1993. Temperature and seed moisture govern storage duration and germination of Phlox drummondii. HortScience 28:185-188.

Copeland, L.O. 1976. Principles of seed science and technology. Burgess, Minneapolis, Minn.

Davis, T.D., S.W. George, A. Upadhyaya, and
J.M. Parsons. 1991 Improvement of seedling emergence of Lupinus texensis Hook. following seed scarification treatments. J. Environ. Hort. 9:17-21.

Davis, T.D., S.W. George, W.A. Mackay, J.M. Parsons. 1994. Development of texas bluebonnets into floricultural crops. HortScience 29:1110, 1211.

Horn, P.E. and G.D. Hill. 1974. Chemical scarification of seeds of Lupinus cosentinii Guss. J. Austral. Inst. Agr. Sci. 40:85-87.

Mackay, W.A. and T.D. Davis. 1998. 'Texas Sapphire' and 'Texas Ice' longstem bluebonnets (Lupinus havardii). HortScience 33:348-349.

Mackay, W.A. T.D. Davis, and D.E. Riemenschneider. 1996. Factors influencing seed germination of Lupinus perennis. J. Environ. Hort. 14:167-169.

Mackay, W.A., T.D. Davis, and D. Sankhla. 1995. Influence of scarification and temperature treatments on seed germination of Lupinus havardii. Seed Sci. Technol. 23:815-822.

Mackay, W.A., J.M.. Parsons, G. Grant, S.W. George, T.D. Davis, and L.A. Stein. 2000. 'Texas Maroon' Bluebonnet (Lupinus texensis Hook.). HortScience 35:313.

Mackay, W.A., T.D. Davis and D. Sankhla. 2001. Influence of scarification and temperature on seed germination of Lupinus arboreus. Seed Sci. Technol. 29:543-548.

Parsons, J.M. and T.D. Davis. 1993. 'Abbott Pink' bluebonnet (Lupinus texensis Hook.). HortScience 28:65-66.

Parsons, J.M., T.D. Davis, S.W. George, and W.A. Mackay. 1994. 'Barbara Bush'bluebonnet (Lupinus texensis Hook.). HortScience 29:1202.

Roberts, E.H. 1972. Viability of seeds. Syracuse Univ. Press, Syracuse, New York.

Shedron, K.G. and T.C. Weiler. 1982. Regulation of growth and flowering in Lupinus Russell-hybrid. HortScience 17:807-809. 